\title{
Integrating a Mediated Learning Experience with Karlstad-model: A Longitudinal Study on a One-Year-Old Child with Down Syndrome
}

\author{
Francesca Granone ${ }^{1}$, Sandra Damnotti ${ }^{2} \&$ Chiara Chicco $^{3}$ \\ ${ }^{1}$ Department of Early Childhood Education, Faculty of Social Science and Humanities - Universitetet i Stavanger \\ (Norway) \\ ${ }^{2}$ International Center for Studies on Educational Methodologies (ICSEM), Italy \\ ${ }^{3}$ MEDIATION A.R.R.C.A., Italy \\ Correspondence: Francesca Granone, University of Stavanger, Norway.
}

Received: May 28, 2021

doi:10.11114/ijsss.v9i4.5277
Accepted: June 25, $2021 \quad$ Available online: June 28, 2021

URL: https://doi.org/10.11114/ijsss.v9i4.5277

\begin{abstract}
The study intends to raise a discussion regarding the question of whether a Mediated Learning Experience (MLE) can be considered applicable to children younger than two years with Down Syndrome (DS), to stimulate their cognitive abilities. In fact, currently MLE approach is used mainly for children of at least two years of age. The longitudinal study has been conducted for six months with a one-year-old child with DS (named T.) between 12 and 18-months of age. Sessions of video recording was conducted each week, videotaping the boy and his mother interacting in different object permanence and cause-effect activities. The article presents first a discussion about similar characteristics that can be identified between MLE and the Karlstad-model, an established approach used regularly in Norway to enhance the communication abilities of children with DS already from the first months. Then, the research presents and discusses how simple activities used also to introduce the Karlstad-model for enhancing child's communication ability can be used to support specific cognitive functions. The study raises interest about the possibility of defining activities suitable for an MLE approach with focus on children younger than two years of age with DS. The results obtained are not generalizable but provide a starting point for discussion that opens up to possible qualitative and quantitative subsequent studies carried out on larger populations.
\end{abstract}

Keywords: mediated learning experience, cognitive development, down syndrome, karlstad-model, cognitive functions

\section{Introduction}

\subsection{Early Intervention in Sustaining the Development and Learning of Children with Disabilities}

The application of a Mediated Leaning Experience (MLE) to children who has learning disabilities or learning difficulties has been extensively studied in the literature and the benefits of this approach have been clearly presented (Feuerstein et al., 1991; Howie, 2019; Lebeer, 2016). The MLE approach outlines different intervention criteria that allow children and young people to be supported in their development, regardless of their functional level (Vigoya, 2005). As it is well known, in the case of disability, a timely intervention in supporting all the child's functions is considered important, regardless of whether the disability is related to communicational, intellectual or motor skills (Kim et al., 2017; Yamauchi et al., 2019; Özçalışkan et al., 2017). This is confirmed also for children with Down Syndrome (DS), which is the most commonly identified genetic form of disability (Bull, 2020). DS can affect all those three aspects, but programs and different approaches have been introduced to sustain and enhance each person's best abilities (Bull, 2020; Kendall, 2019). In Norway, children with DS receive a support in their language development already from the first months, through an approach called Karlstad-model (Djurman \& Jakobsson, 2014). The interest of this study, named BAToM project (Babies And Toddlers Mediated learning experience) and generated from the cooperation between the University of Stavanger and the International Center for Studies on Educational Methodologies (ICSEM), is to rise a discussion about the possibility of sustaining cognitive development of children with DS already from the birth through a Mediated Learning Experience.

\subsection{Karlstad Model as a Method for Enhancing Communication Abilities in Children with DS}

In Norway children with disabilities or difficulties in learning the language receive a support through a method called 
the Karlstad-model already from the first months (Ingemarsson \& Ovstebo, 2008). The Karlstad-model is a theoretical model that was developed in 1970 for individuals who needed a support in their language learning process, such as children with mental or perceptual difficulties, hearing difficulties, multilingual background. It combines theories related to speech and language learning with a model of practice. This approach has been studied deeply and applied with preschool children, and its efficacy has been provided (Johansson, 1997; Johansson, 2006a; Johansson, 2006; Johannson, 2007). The model has two aims, the first related to preparing the children for the social use of spoken and written language, the second related to preparing the children for the cognitive use of language in order to facilitate skills as problem-solving, memory and thought processes (Djurman \& Jakobsson, 2014; Ingemarsson \& Ovstebo, 2008).

\subsection{The Importance of MLE Approach}

Based on the second aim of the Karlstad-model, the hypothesis of introducing the MLE approach already in children younger than two years of age seems interesting. The MLE is an approach that has been applied and specifically developed in different ways, depending on the age of the children who receive the support. The Feuerstein Instrumental Enrichment Standard Program is designed for children from eight-years of age (Kloppers \& Grosser, 2010), whereas the Feuerstein Instrumental Enrichment Base Program is thought for children already from two-years of age (De Robertis, 2018). Those approaches are based on activities that are presented to children in order to stimulate their emerging cognitive functions, to enhance then their development (Cornea \& Todor, 2019). An approach always grounded on the MLE approach, but more related to group activities and plays for children from three-years of age, is called Bright Start and has been developed by (Haywood, 2013). The reliability of those methods in enhancing the children's cognitive development is well known (Cornea \& Todor, 2019; Howie, 2019; Todor \& Gomoescu, 2019). Despite this, there are no studies that observe, analyse or define the MLE approach for children under 2 years of age.

\subsection{Research Questions}

For those reasons a research question has been defined: "Based on similarities between MLE and the Karlstad-model, can be raised the interest in defining specific activities aimed to introduce the MLE approach to children with DS younger than two years of age in order to enhance their cognitive functions?" A longitudinal study has been conducted to collect data and generate reflections that should be used as stimulus for investigating this idea more in depth.

\section{Theoretical Framework, Context and Method}

\subsection{Theoretical Framework}

The study is grounded on two approaches: the Karlstad-model (Ingemarsson \& Ovstebo, 2008) and the Mediated Learning Experience approach (Lebeer, 2016). In particular, it is based on some characteristics of the two theories that can be identified as common.

The Karlstad-model promotes language development from pre-linguistic until reading and writing at school age (Johansson, 2010). The theoretical part important for the present study is the one focused on child's pre-linguistic development. Karlstad model is based on Vygotsky theories (Veraksa \& Sheridan, 2018) and the child is considered as a subject that needs emotional and psychological guidance (Ingemarsson \& Ovstebo, 2008). Fundamental characteristics of this approach is the empowerment, that means that the knowledge is given to the child when he needs it. A framework of the model can be identified in a holistic perspective of child's development (Bloom \& Lahey, 1978; Smith, 2007) and in the importance given to pragmatism, so that a meaning is identified beyond the syntactic information and the child is invited in finding linking between a new information and an old one (Ingemarsson \& Ovstebo, 2008). The child then is active in the learning process and learns through his own experience. Important characteristics are also that the intervention offered to the child through the Karlstad-model has to be personalized specifically on child's specific difficulties and has to be offered by an educational community (teachers, parents, caregivers, ...). priming and training the child's listening and attention skills. Interacting with others through playing, listening, looking, imitating and touching, the child learns the importance and the enjoiment of communication. The model has implemented 12 programmes along with proposals for activities and materials (Johansson, 1988) are focused upon turn-taking, speech/sound listening patterns, tactile communication, mirroring and alternative communication.

Many of the aspects described for the Karlstad-model can be identified also in the MLE approach (Cornea \& Todor, 2019; Feuerstein et al., 1991). It can be described through 12 criteria, three identified as universals and nine additionally (Vigoya, 2005). Those criteria are described in Table 1: 
Table 1.12 criteria of MLE

\begin{tabular}{|c|c|c|}
\hline Criteria & Name & Explanation \\
\hline 1 & Intentionality and reciprocity & $\begin{array}{l}\text { The mediator shows his intentions to the children, with the aim of involving } \\
\text { them in a mutual process of learning. It is fundamental that the mediator verify } \\
\text { children's understanding about what is the goal of the activity. }\end{array}$ \\
\hline 2 & Transcendence & $\begin{array}{l}\text { The mediator helps the children to use an acquired knowledge to new } \\
\text { situations. }\end{array}$ \\
\hline 3 & Significance & $\begin{array}{l}\text { The mediator explains the intention of the activities in order to give them } \\
\text { sense. He/she should raise children's interest in the task itself. }\end{array}$ \\
\hline 4 & Planning and achieving objectives & $\begin{array}{l}\text { The mediator helps children to set their objectives and to approach them with } \\
\text { perseverance, patience and hard work. }\end{array}$ \\
\hline 5 & Sense of competence & $\begin{array}{l}\text { The mediator has the responsibility of creating an environment where children } \\
\text { can develop high self-esteem and self-confidence, as a means for acquiring the } \\
\text { necessary abilities and strategies. This can be realized adapting activities } \\
\text { according to children's interests and ages. }\end{array}$ \\
\hline 6 & Awareness of change & $\begin{array}{l}\text { The mediator helps children in becoming aware about the fact that they can } \\
\text { change, improve and strengthen their cognitive functions and their behaviours } \\
\text { and strategies in order to achieve their objectives. }\end{array}$ \\
\hline 7 & Novelty and complexity & $\begin{array}{l}\text { The mediator presents challenges to the children. The activities organised } \\
\text { should be sufficiently difficult to provide a challenge, but still achievable. }\end{array}$ \\
\hline 8 & $\begin{array}{l}\text { Active participation and shared } \\
\text { conduct }\end{array}$ & $\begin{array}{l}\text { The mediator promotes collaborative work, with pupils and among pupils. } \\
\text { This increase socialisation, discussion, agreement, but also cognitive and } \\
\text { socio-emotional growth. }\end{array}$ \\
\hline 9 & Regulation and control of conduct & $\begin{array}{l}\text { The mediator helps children in developing logical and systematic processes to } \\
\text { solve problems by using previously acquired knowledge, expressing it through } \\
\text { reasoning procedures. }\end{array}$ \\
\hline 10 & $\begin{array}{l}\text { Individuality and psychological } \\
\text { difference }\end{array}$ & $\begin{array}{l}\text { The mediator strengths the importance and the richness of being unique person } \\
\text { with different thoughts and different learning processes. }\end{array}$ \\
\hline 11 & Sense of belonging & $\begin{array}{l}\text { The mediator promotes teamwork and reinforces reciprocal support, tolerance, } \\
\text { respect, confidence, empathy. }\end{array}$ \\
\hline 12 & Optimistic awareness & $\begin{array}{l}\text { The mediator underlines that it is not important how difficult an activity seems } \\
\text { to the children, because they have to trust in themselves and believe that they } \\
\text { will reach the goal. }\end{array}$ \\
\hline
\end{tabular}

As can be deduced, similarities can be found between some MLE criteria and some characteristics of the Karlstad-model. In particular, two can be identified as relevant for the present study. One is the criteria "Trascendence". It means, in fact, that the mediator should help the child in understanding that he/she is acquiring a knowledge that will be applied and used in other situations, finding links between a new information and an old one, similarly to what happens through the Karlstad-model. The other one is the criteria of "Individuality and psychological difference", that can be compared to the personalization necessary for the effective application of the Karlstad-model. These and other similarities suggested to the researchers to start an investigation to see whether the MLE approach can be considered adaptable also to children younger than two years of age.

One peculiar aspect of the MLE approach is that the mediator can identify specific cognitive functions that the child uses, or should use, during the activities (Haywood, 2013). The cognitive functions (CF) interesting for this research project are identified with an abbreviation (from $\mathrm{FC1}$ to $\mathrm{FC12}$ ). A classification of those cognitive functions, is presented in Table 2, accordingly to the Pas Basic description (Kloppers \& Grosser, 2010):

Table 2. Emerging cognitive functions

\begin{tabular}{lcc}
\hline Input & Elaboration & Output \\
\hline FC1: increase of the attention span & FC7: concept pass time & FC12: ability to provide precise answers \\
FC2: focus of attention & FC8: knowledge of logical progression of & \\
& events & \\
FC3: discrimination of stimuli & FC9: knowledge of problem-solving stages & \\
FC4: identification of relevant stimuli & FC10: increase abstract thinking & \\
FC5: increase of verbal skills & FC11: use of symbols and verbal code & \\
FC6: orientation increase & & \\
\hline
\end{tabular}

Another specific aspect of the MLE approach is the level of intervention of the adult (Howie, 2019). The adult can be really active in his role, moving child's hand (this is called "Level 0 of mediation") but has to move toward to a situation in which the child reach a higher level of independence (the higher level applicable for a child younger than two years of age is the one identified as "Level 3 of mediation"). Even further levels (named level 4 until level 9) are not relevant for this study.

The mediation levels from 0 to 3 are described in Table 3: 
Table 3. Level of mediation

\begin{tabular}{lll}
\hline Level of mediation & Role of the mediator & Attitude of the child \\
\hline 0 & $\begin{array}{l}\text { Produces the response by acting } \\
\text { on the child } \\
\text { Activates a model to copy }\end{array}$ & $\begin{array}{l}\text { He/She has a passive attitude } \\
\text { He/She begins to partially } \\
\text { respond actively }\end{array}$ \\
$\begin{array}{l}\text { Orientates the child's response } \\
\text { with indications and explanations }\end{array}$ & $\begin{array}{l}\text { He/She spontaneously responds to } \\
\text { the task and pays attention to the } \\
\text { mediator's instructions } \\
\text { He/She spontaneously solves the } \\
\text { task }\end{array}$ \\
\hline
\end{tabular}

It is interesting to highlight that, also if this scale is specific to the MLE approach, a gradation in adult's role can be similarly described in the Karlstad-model (Johansson, 2010)

\subsection{Context}

The study involved a one-year-old child with DS, between 12 and 18-months of age. The choice of the child with DS was based on the fact that the mother was an MLE trainer and that she had an open dialogue on the Karlstad-model with the special pedagogue in charge of supporting the child in his development, as well as with the researchers.

\subsection{Method}

The present research is a longitudinal study. Based on the common aspects identified and described in the theoretical section, different activities have been prepared and designed in order to involve for six months a one-year-old child with DS, between 12 and 18-months of age, and to observe his development. Daily activities with the approach based on the Karlstad-Model were presented in the kindergarten, in order to enhance child's communication ability. Those activities were described to the mother and registered in a book from the special teacher in the kindergarten who was working with $\mathrm{T}$. The book was collected by the mother weekly, and the home activities were designed similarly. The activities between the mother and the child were implemented twice a week, for 20 minutes, and were based on a MLE approach. Videorecording was conducted by the mother, and afterward these were analyzed and discussed among researchers, in order to observe how the same activities presented for having an impact on child's communication abilities had also an impact on child's cognitive functions. Because the project was focused on a one-year-old child with DS, the interest was about FC1, FC2, FC3, FC4, FC5, FC6, FC8, FC9. In the description "verbal competence" the body language was included.

The activities presented to the child both in kindergarten and at home, that are analysed in this study, can be devided in two main categories: object-permanence and cause-effect:

Table 4. Activities

\begin{tabular}{ll}
\hline Main category & \multicolumn{1}{c}{ Activities } \\
\hline Object-permanence & A1: Hiding an object behind the mediator \\
& A2: Hiding an object in a glass \\
& A3: Hiding an object under a box \\
& \\
Cause-effect & A4: Pull a tissue to catch something on top of it \\
& A5: Pull a rope for raising a curtain \\
& A6: Press a button for showing a toy out of a box \\
\hline
\end{tabular}

Those activities have been selected because are related to key skills that children with DS should achieve for their development (Henry, 2014). The modification of child's understanding (indicated as a reduction in child's reaction time between the stimulus and the response) and consequently the adult's level of mediation needed during the activities will be presented and discussed.

\section{Results and Discussion}

\subsection{Definition of the Child's Initial Cognitive Functions}

In order to respect the criteria that the MLE approach define as "Individuality and psychological difference", the first week of the study was focused on defining child's initial cognitive functions, studying child's reaction during object-permanence and cause-effect activities.

For observing the comprehension of the object-permanence, activities related to hiding a toy were chosen (see Table 2). To rise child's interest, a specific ball that T. liked very much was chosen. The mother showed the ball to T. and let him play with it for some minutes. Afterwards, she hided the object while he watched. The child clearly showed an understanding of the object-permanence, moving himself with the intent of reaching the ball hidden behind the mediator (A1), in a glass (A2) or under a box (A3). Without problem or doubt T. was able to move immediately in the correct direction. The observations showed that T. had already a good level of attention (FC2) that could last a time long 
enough to solve the problem (FC1), as well as the ability of orientation in space (FC6). The cognitive functions "Discrimination of stimuli" (FC3) and "identification of stimuli that are relevant" (FC4) were present. However, the verbal competences were not yet developed. T. had no ability in asking or communicating, because he couldn't communicate what he wanted when he couldn't reach the ball by himself (FC5).

In the same week, the activities related to cause-effect were presented to the child. While the activities of pulling tissue to catch something on top of it (A4) and pulling a rope for raising a curtain (A5) were executed by the child without problems, the activity of pressing a button to get a toy out of a box (A6) was not carried out. The cognitive functions highlighted with the previous set of activities (main category object-permanence) were confirmed, but no communication's intent was present (FC5) and the comprehension of logical sequence of events (FC8) and sequence of the problem-solving procedure (FC9) were still not completely confirmed.

After those observations the researchers decided to have focus on the two cognitive functions that were "emergent" in T.: FC5 and FC8. Researchers considered that FC8 was necessary for developing FC9, so the development of FC9 has not been taken into account in this study.

\subsection{The Development of the Cognitive Function FC5 During the Longitudinal Study}

In order to have focus on the cognitive function FC5, the researchers decided to stimulate the child through the activity A3. Since the child was already able to perform the activity but not to communicate, it was decided to prepare the environment in such a way that $\mathrm{T}$. was necessarily led to ask for help through the body or the voice. To do this, the child was placed in a comfortable chair, at a certain distance from the ball and the box. When the ball was hidden the child could get the ball back only by pointing to the box under which the ball had been hidden. The activity was carried out starting from a level of mediation 0 , in which the mother guided the child's hand to point, in order to receive back the ball as a reward. During the study, the time that the child used for establishing a communication was measured. When the previous level seemed to be acquired (time of child's reaction lower than $10 \mathrm{~s}$ ), the mother moved to a higher level of mediation (and so a lower level of intervention).

Here below are reported the graphs of the time used by the child to react correctly to the activity over the months, differentiated by the level of mediation (Figure 1, Figure 2, Figure 3, Figure 4).

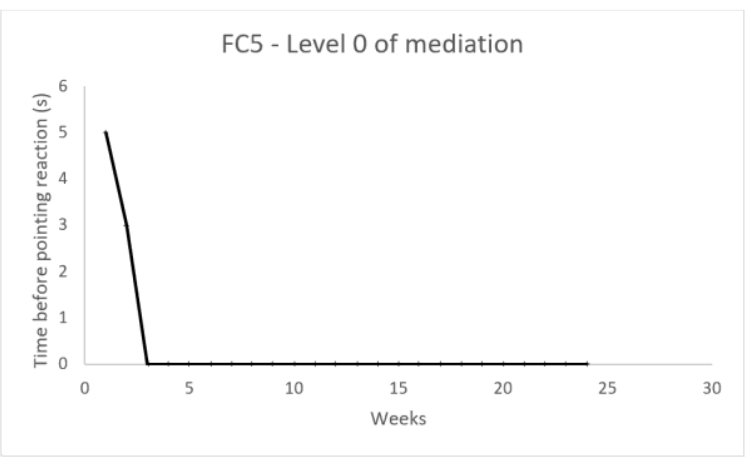

Figure 1. FC5 - Level 0 of mediation

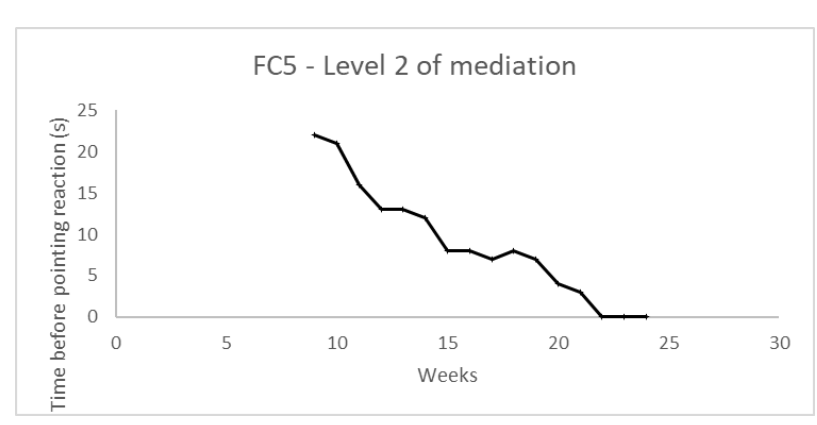

Figure 3. Level 2 of mediation

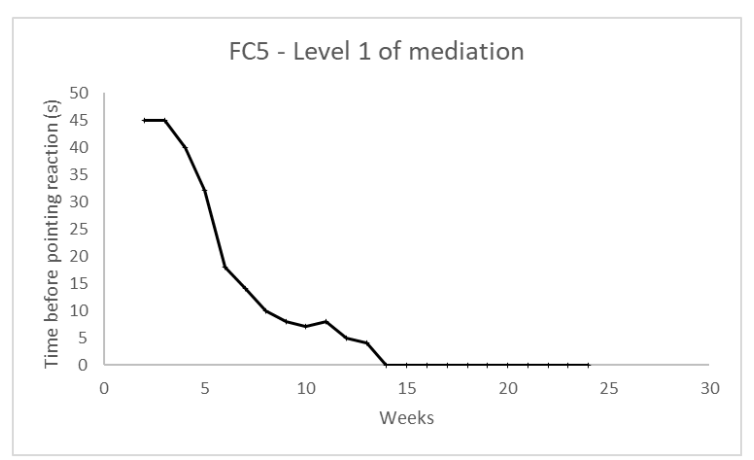

Figure 2. FC5 - Level 1 of mediation

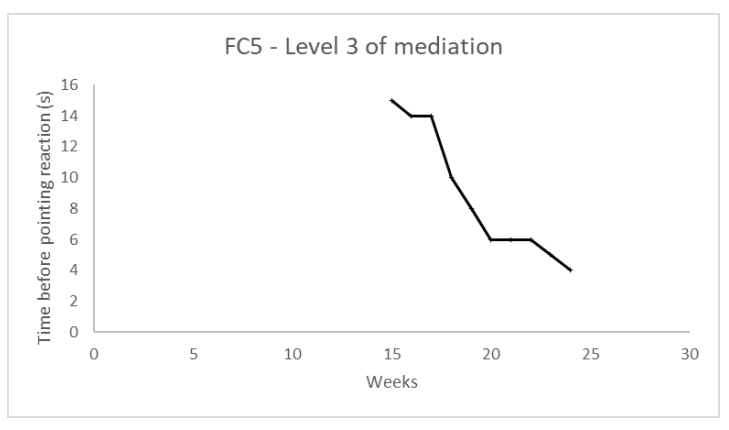

Figure 4. Level 3 of mediation 
In each graph is possible to understand the quickness of child's reaction when a specified level of mediation is applied. Figure 1 shows that a level 0 of mediation helps the child to become outonomous already after 2,5 weeks, whereas it takes longer time with the others level of mediation. If we compare child's reaction between level 1 (Figure 2) and level 3 (Figure 4), we can anyway observe that the more time the child spends in the project, the faster his learning becomes.

From the evolution of graphs can be deduced that the intervention of mediation has been useful to the child. In fact, the child develops an understanding, and the learning process becomes quicker when the level of mediation increases (and this means that the intervention of the mother is reduced).

\subsection{The Development of the Cognitive Function FC8 During the Longitudinal Study}

In order to have focus on the cognitive function FC8, the researchers decided to stimulate the child through the activity A6. The child was sitting in front of a pop-up toy. This was constituted by four buttons in a row that controlled four animals, one each. The animal corresponding to the button appeared when the button was pressed.

For two weeks the child was sitting in front of the toy, moving the whole toy without pressing the buttons. The mediation at 0 level conducted by the mother was not helping the child in his participation to any activity. The mother tried to guide the child in the understanding of the criteria "Transcendence", but without results. After two weeks, the toy was substituted with one identical, except that a sound was produced when the button was pressed. This attempt totally changed the attitude of T., who began to show a real interest and to proceed in learning. This confirmed one of the important criteria of the MLE approach and of the Karlstad-model: the child has to be reached precisely where he is, making use of its interests.

Here below are reported the graphs of the time used by the child to react correctly to the activity over the months, differentiated by the level of mediation (Figure 5, Figure 6, Figure 7, Figure 8). If we compare child's reaction between level 1 (Figure 6) and level 3 (Figure 8), we can observe that again the more time the child spends in the project, the faster his learning becomes. The higher level of mediation was started by the mother when the previous level seemed to be acquired (time of child's reaction lower than $10 \mathrm{~s}$ ).

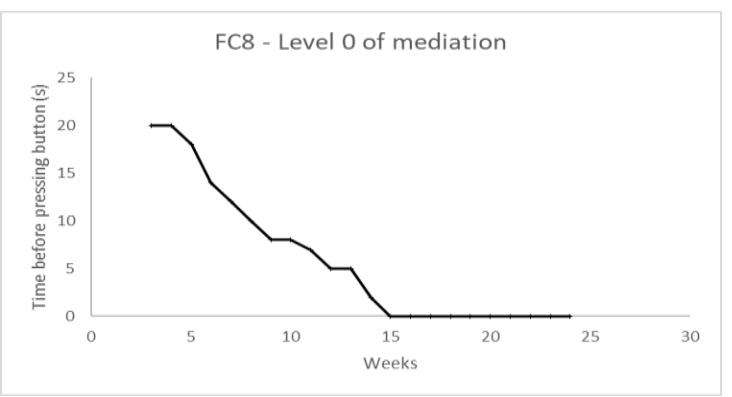

Figure 5. FC8 - Level 0 of mediation

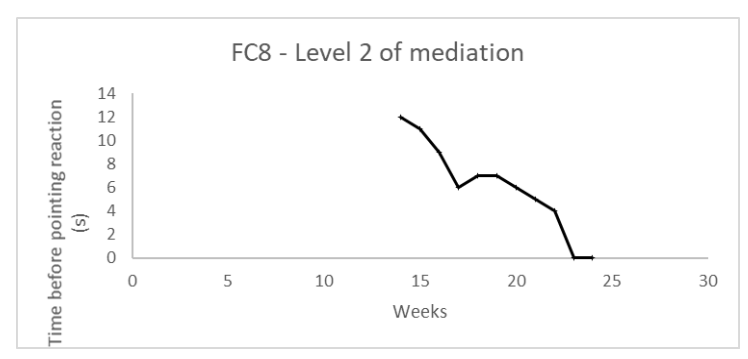

Figure 7. FC8 - Level 2 of mediation

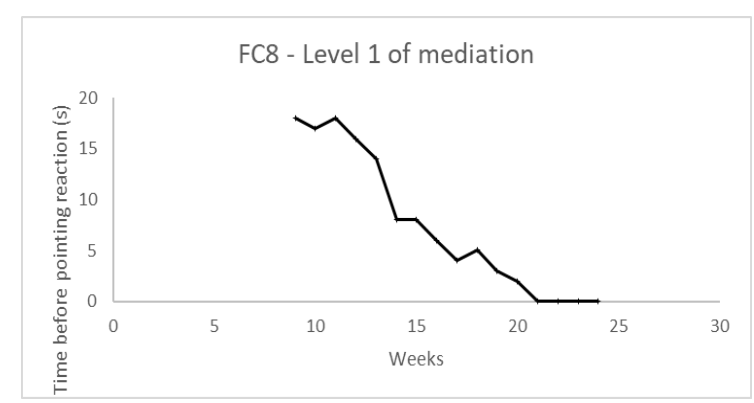

Figure 6. FC8 - Level 1 of mediation

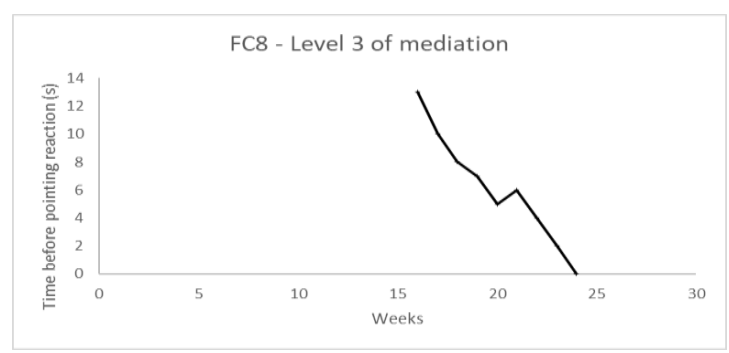

Figure 8. FC8 - Level 3 of mediation

Results show that, once obtain the interest of the child, the intervention of the mediator allow a development of the understanding about the cause-effect relation. Child's development becomes faster as the child's level of independence increases. This is not a generalizable principle and more in-depth studies (especially on a larger sample) should be carried out.

The research has presented limits, related to the fact that just one child was involved. This does not allow a generalization or the identification of an effect on child's learning as a consequence of the intervention. However, the intention of this study is to rise the attention about the fact that a MLE approach for children with DS younger than two 
years of age should be grounded investigated. An interesting effect that is important to highlight is that when the child achieved the ability to communicate pointing with the finger during the activities, he expressed this competence also more generally, starting a simple but clear communication's attempt in different areas, such as asking for toys, or asking for food. It is important to underline that this it is impossible to identify the MLE approach as the only factor responsible of this development, because during this study, the child continued to be solicited through the Karlstad-model in kindergarten. Then, the present study can only state that the child's development happened, and that the level of mediation could be reduced as the child grew and the study evolved.

A research where children with DS younger than two years of age receive only a MLE approach could be interesting.

\section{Conclusion}

In accordance with the aim of the study, the research project presented here raises a discussion regarding the question of whether a Mediated Learning Experience (MLE) can be considered applicable to children with DS younger than two years of age, as a means for stimulating their cognitive abilities. Results show that T. seems supported and encouraged in his development by the MLE approach received at home, while at the same time support through the Karlstad model was provided in kindergarten. The limitations of the study, linked to the fact that only one child was involved in the longitudinal study and to the fact that it is not possible to isolate the effect due to the MLE alone, should however arise interest in the evaluation of specific activities that allow an MLE approach on children under the age of two. These activities should contain an articulated and clear definition of how the individual cognitive functions are stimulated, as well as the way in which the assessment could be carried out. Furthermore, attention should also be placed on the progression of the role of the mediator who from a level of strong presence should slowly pass to that of spectator.

\section{Acknowledgements}

The present study, part of the project named BAToM (Baby And Toddlers Mediated learning experience) is the result of a partnership between the University of Stavanger and the association ICSEM (International Center For Studies On Educational Methodologies). The study has been financied by ICSEM.

\section{References}

Bloom, L., \& Lahey, M. (1977). Language development and language disorders. New York: John Wiley \& Sons Ltd.

Bull, M. J. (2020). Down syndrome. New England Journal of Medicine, 382(24), 2344-2352. https://doi.org/10.1056/NEJMra1706537

Cornea, G., \& Todor, O. (2019). The influence of the feuerstein method in the psychological development of preschool. Bulletin of the Transilvania University of Brasov. Series VII, Social Sciences and Law, 12(2), 223-228.

De Robertis, S. (2018). Esperienza apprendimento mediato di Revenue Feuerstein per una didattica inclusiva. Segni $e$ comprensione, 93, 23-36.

Djurman, J., \& Jakobsson, S. (2014). Barn med Downs syndrom : Pedagogers arbetssätt kring språk och interaktion i förskolan (Dissertation). Retrieved from http://urn.kb.se/resolve?urn=urn:nbn:se:uu:diva-239169

Feuerstein, R., \& Feuerstein, S. (1991). Mediated learning experience: A theoretical review. In R. Feuerstein, P. S. Klein, \& A. J. Tannenbaum (Eds.), Mediated learning experience (MLE): Theoretical, psychosocial and learning implication (pp. 3-51). London: Freund.

Haywood, H. C. (2013). What is cognitive education? the view from 30,000 feet. Journal of Cognitive Education and Psychology, 12(1), 26-44. https://doi.org/10.1891/1945-8959.12.1.26

Henry, J. (2014). Early communication skills for children with Down syndrome: A guide for parents and professionals. The Canadian Journal of Occupational Therapy, 81(1), 67. https://doi.org/10.1177/0008417413501800

Howie, D. R. (2020). Thinking About the Teaching of Thinking: The Feuerstein Approach. Abingdon, Oxon: Routledge. https://doi.org/10.4324/9780429316074

Ingemarsson, M., \& Ovstebo, B. (2008). Language Intervention in Daily Life: The Karlstad Model of Language Learning. Sorlandet and Statped West Support Centres. Norwegian Support Centre for Special Needs Education. Retrieved from http://www.karlstadmodellen.se/artiklar/language_intervention_in_daily_life

Johansson, I. (1988). Språkutveckling hos handikappade barn: Performativ kommunikation. Lund: Studentlitteratur.

Johansson, I. (1997). Samarbete, habilitering, barnomsorg, hem och skola: modell för kontinuitet i språkträning av barn med uttalade inlärningsproblem (Arbetsrapport nr 3: Handikapp och språk). Karlstad: Karlstad University.

Johansson, I. (2006a). Prosjektrapport, Talutveckling hos små barn med cochleaimplantat, en interventionsstudie, Karolinska Universitetssjukhuset, Sektion för cohhleamplantat. Sweden. 
Johansson, I. (2006b). Utbyggd grammatik: Spåkträning enligt Karlstadmodellen. Hatten Publishing Sweden.

Johansson, I. (2007). Talträning. Hatten Publishing, Sweden.

Johansson, I. (2010). Karlstadmodellen. Lastet ned fra http://www.karlstadmodellen.se

Kendall, L. (2019). Supporting children with Down syndrome within mainstream education settings: parental reflections. Education 3-13, 47(2), 135-147. https://doi.org/10.1080/03004279.2017.1412488

Kim, H. I., Kim, S. W., Kim, J., Jeon, H. R., \& Jung, D. W. (2017). Motor and cognitive developmental profiles in children with Down syndrome. Annals of rehabilitation medicine, 41(1), 97. https://doi.org/10.5535/arm.2017.41.1.97

Kloppers, M., \& Grosser, M. (2010). Exploring the impact of Feuerstein's Instrumental Enrichment Programme on the cognitive development of prospective mathematics educators. The Journal for Transdisciplinary Research in Southern Africa, 2, e1. https://doi.org/10.4102/td.v6i2.264

Lebeer, J. (2016). Significance of the Feuerstein approach in neurocognitive rehabilitation. NeuroRehabilitation, 39(1), 19-35. https://doi.org/10.3233/NRE-161335

Özçalışkan, Ş., Adamson, L. B., Dimitrova, N., \& Baumann, S. (2017). Early gesture provides a helping hand to spoken vocabulary development for children with autism, down syndrome, and typical development. Journal of Cognition and Development, 18(3), 325-337. https://doi.org/10.1080/15248372.2017.1329735

Smith, S. D. (2007). Genes, language development, and language disorders. Mental retardation and developmental disabilities research reviews, 13(1), 96-105. https://doi.org/10.1002/mrdd.20135

Todor, O., \& Gomoescu, M. (2019). The importance of mediated learning in primary school education1. Bulletin of the Transilvania University of Brasov. Series VII, Social Sciences and Law, 12(2), 295-314. https://doi.org/10.31926/but.ssl.2019.12.61.2.13

Veraksa, N. och Sheridan, S. 2018., red. Vygotsky's Theory in Early Childhood and Research. Russian and Western values 3-8: 206-213. London: Routledge. https://doi.org/10.4324/9781315098203-16

Vigoya, F. S. T. (2005). The Mediated Learning Experience and the Mediator's Implications. Profile: Issues in Teachers' Professional Development, 6(1), 177-185.

Yamauchi, Y., Aoki, S., Koike, J., Hanzawa, N., \& Hashimoto, K. (2019). Motor and cognitive development of children with Down syndrome: The effect of acquisition of walking skills on their cognitive and language abilities. Brain and Development, 41(4), 320-326. https://doi.org/10.1016/j.braindev.2018.11.008

\section{Copyrights}

Copyright for this article is retained by the author(s), with first publication rights granted to the journal.

This is an open-access article distributed under the terms and conditions of the Creative Commons Attribution license which permits unrestricted use, distribution, and reproduction in any medium, provided the original work is properly cited. 